\title{
Filtering Concept for Web Learning
}

\author{
G. Michael, C. Nalini, C. Geetha
}

\begin{abstract}
The fast development of the WWW presents uncommon difficulties for broadly useful crawlers and web crawlers. The Former strategy used to slither site pages was FOCUS (Forum Crawler Under Supervision).This undertaking presents an aggregate conduct learning calculation for web creeping. The aggregate conduct learning calculation creep the site pages dependent on specific watchword. Discriminative learning removes just the related URL of the specific catchphrase dependent on separating. The objective of this venture is to creep applicable gathering content from the web with negligible overhead. The undesirable URL is expelled from the website pages and the site page slithering is decreased by utilizing the aggregate conduct learning. The site pages must be removed dependent on certain learning procedures and can be utilized to gather the undesirable URL'S.
\end{abstract}

Keywords-Uniform Resource Locator, World Wide Web, Support Vector Machine, Forum Crawler Under Supervision.

\section{INTRODUCTION}

Information mining is the way toward examining information from various fields and outlining it into helpful data. Information mining programming is one of the expository apparatuses for breaking down information. Clients can examine information from a wide range of regions and outlines the connections recognized. Information mining is the way toward discovering information or examples in enormous social databases for gathering various information. With the development of information retrieval websites have become a more and more important information medium for different organizations and people all over the world. The information is distributed on the web pages with some unwanted URL'S. The major aim of this project is to remove the unwanted URL'S. In this method for learning regular expression patterns of URLs that lead a crawler from an entry page to target pages. In the underlying investigation, measured quality augmentation was utilized to separate social URL. The prevalence of this system over other agent social learning techniques has been confirmed with web-based social networking information URL. The genuine system, be that as it may, isn't adaptable to deal with enormous sizes in light of the fact that the removed social URL measurements are fairly thick. In social pages, a system of a huge number of URL is extremely normal. With an enormous number of URL separated can't be held some of the time in memory, causing a genuine

Revised Manuscript Received on December 11, 2019

G.Michael *, Department of CSE, Bharath Institute of Higher Education and Research, Chennai, Tamilnadu, India.

C. Nalini, Department of CSE, Bharath Institute of Higher Education and Research, Chennai, Tamilnadu, India.

C. Geetha, Department of CSE, Bharath Institute of Higher Education and Research, Chennai, Tamilnadu, India. computational issue. Information mining utilizes data from past information to break down the result of a specific issue or circumstance that may emerge. Information mining works by dissecting information put away in information distribution centers that are utilized to store that information that is being grabbed to examine. The information may originate from all pieces of business, from the generation to the administration. Directors use information mining to settle on showcasing systems for their own item created.

An ongoing system dependent on social URL'S measurements is demonstrated to be compelling in tending to this heterogeneity. The system demonstrates a superior method for URL order: first, catch the inert affiliations of on-screen characters by extricating social measurements based and next, apply precise information mining procedures to characterization dependent on the separated measurements. The collective behavior learning algorithm provides the basis for converting the wanted and unwanted URL. The web page is extracted based on certain URL extraction features and can be based on dimensional values. The unwanted URL'S are found based on certain features and can be extracted with social values. There are different sorts of significant semantic data about true elements installed in website pages and databases. Extricating and coordinating the needed data from the Web is of incredible hugeness. To extract the dimension of the web pages regularization is applied. Learning customary articulation examples of URLs that lead a crawler from a section page to target pages. In the underlying investigation, measured quality expansion was utilized to remove social URL. The predominance of this system over other agent social learning techniques has been checked with web based life information URL. The first system, nonetheless, isn't adaptable to deal with systems of sizes on the grounds that the extricated social URL measurements are somewhat thick. In social media, millions of URL'S are very common. With a huge number dimensions cannot even, causing a serious computational problem.

\section{LEARNING ALGORITHM}

The collective behavior learning algorithm provides the basis for converting the wanted and unwanted URL. The web page is extracted based on certain URL extraction features and can be based on dimensional values. The unwanted URL'S are found based on certain features and can be extracted with social values. There are different sorts of significant semantic data about certifiable substances inserted in website pages and databases. 
Extricating and coordinating these substance data from the Web is of incredible noteworthiness. Regularization is applied to separate the component of the site pages.

\section{STEPS IN COLLECTIVE BEHAVIOUR LEARNING}

Input: arrange information, marks of some URL, number of social URL measurements;

Output : marks of undesirable URL.

Steps:- 1. Convert arrange into edge-driven view.

2. Perform edgeclustering.

3. Construct social URL measurements dependent tense parcel hub has a place with one network as long as any of its neighboring edges is in that network.

4. Apply regularization to social URL measurements.

5. Construct classifier dependent on social URL measurements of named hubs.

6. Use the classifier to foresee marks of undesirable ones dependent on their social measurements.

\section{RESULTS}

\section{A.Authentication:}

In the authentication module user and admin login are used to provide information about the user of the web pages .the user and admin login are defined below

\section{B.User Sign Up And Login:}

In this module user can create account with the sites by filling details. The user can create account by using username and password. The username can consist of alphabet and special characters. The passwords consist of alphabet and numerals. The user will be authenticated only if they provide the correct username and password.

\section{C.Admin Login:}

In admin login the admin has their username and password of their own and they authenticate the users who are entering into the system are authenticated or not. Admin provides a clear view of the system authentication. The admin has the right to create, delete and add pages and users.

\section{DISCUSSION}

The latent social URL dimensions are extracted based on network topology to capture the potential affiliations of URL. These extracted social URL dimensions represent how each actor is involved in diverse affiliations. These social URL dimensions can be treated as features of actors for subsequent discriminative learning. Data is converted into features, important classifiers such as support vector machine and logistic regression can be used. Social dimensions extracted according to the data clustering, such as modularity maximization and probabilistic methods.

\section{CONCLUSION AND FURTHUR SCOPE}

The collective behavior learning algorithm provides an efficient way for extracting the web pages based on wanted and unwanted URL. The web page is extracted based on certain URL extraction features and can be based on dimensional values. The unwanted URL'S are found based on certain features and can be extracted with social values. There are various kinds of valuable semantic information about real-world entities embedded in web pages and databases. Integrating and extracting the entity information from the Web is of great significance.

The social pages will consist of advertisements and different violence and censored URL. This work provides a clear view of extracting wanted and unwanted URL. Social web page extraction is done and the unwanted URL'S in the web pages are removed. This is shown by the screenshots and each value is filtered by using certain discriminative leaning techniques. The main contribution is the web page classification based on different attributes. Social measurements are extricated to speak to the potential affiliations of entertainers before discriminative learning happens. The ways to deal with concentrate social measurements experience the ill effects of versatility, it is basic to address the adaptability issue. Propose an edge-driven bunching plan to separate social measurements and an adaptable k-implies variation to deal with edge grouping. Each edgeis treated as one information instance, and corresponding highlights are the associated hubs.

In our future work filtering the URL'S automatically by using specified tools will be performed. The advance work will limit the unwanted URL'S by applying certain dimension in high capacity values.

\section{REFERENCES}

1. Kumaravel A., Meetei O.N.,An application of non-uniform cellular automata for efficient cryptography,2013 IEEE Conference on Information and Communication Technologies, ICT 2013,V-,I-,PP-1200-1205,Y-2013

2. Kumarave A., Rangarajan K.,Routing alogrithm over semi-regular tessellations,2013 IEEE Conference on Information and Communication Technologies, ICT 2013,V-,I-,PP-1180-1184,Y-2013

3. Dutta P., Kumaravel A.,A novel approach to trust based identification of leaders in social networks,Indian Journal of Science and Technology,V-9,I-10,PP--,Y-2016

4. Kumaravel A., Dutta P.,Application of Pca for context selection for collaborative filtering,Middle - East Journal of Scientific Research,V-20,I-1,PP-88-93,Y-2014

5. Kumaravel A., Rangarajan K.,Constructing an automaton for exploring dynamic labyrinths,2012 International Conference on Radar, Communication and Computing, ICRCC 2012,V-,I-,PP-161-165,Y-2012

6. Kumaravel A.,Comparison of two multi-classification approaches for detecting network attacks,World Applied Sciences Journal,V-27,I-11,PP-1461-1465,Y-2013

7. Tariq J., Kumaravel A.,Construction of cellular automata over hexagonal and triangular tessellations for path planning of multi-robots,2016 IEEE International Conference on Computational Intelligence and Computing Research, ICCIC 2016,V-,I-,PP--,Y-2017

8. Sudha M., Kumaravel A.,Analysis and measurement of wave guides using poisson method,Indonesian Journal of Electrical Engineering and Computer Science,V-8,I-2,PP-546-548,Y-2017

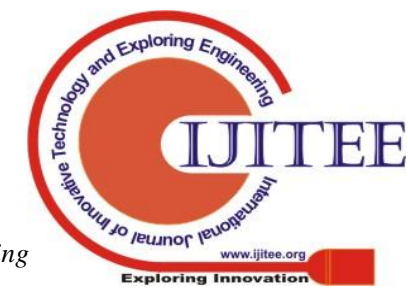


9. Ayyappan G., Nalini C., Kumaravel A., Various approaches of knowledge transfer in academic social network,International Journal of Engineering and Technology,V-,I-,PP-2791-2794,Y-2017

10. Kaliyamurthie, K.P., Sivaraman, K., Ramesh, S. Imposing patient data privacy in wireless medical sensor networks through homomorphic cryptosystems 2016, Journal of Chemical and Pharmaceutical Sciences

11. Kaliyamurthie, K.P., Balasubramanian, P.C. An approach to multi secure to historical malformed documents using integer ripple transfiguration 2016 Journal of Chemical and Pharmaceutical Sciences 9

12. A.Sangeetha,C.Nalini,"Semantic Ranking based on keywords extractions in the web", International Journal of Engineering \& Technology, 7 (2.6) (2018) 290-292

13. S.V.GayathiriDevi,C.Nalini,N.Kumar,"An efficient software verification using multi-layered software verification tool "International Journal of Engineering \& Technology, 7(2.21)2018 454-457

14. C.Nalini,ShwtambariKharabe,"A Comparative Study On Differen Techniques Used For Finger - Vein Authentication", International Journal Of Pure And Applied Mathematics, Volume 116 No. 8 2017, 327-333, Issn: 1314-3395

15. M.S. Vivekanandan and Dr. C. Rajabhushanam, "Enabling Privacy Protection and Content Assurance in Geo-Social Networks", International Journal of Innovative Research in Management, Engineering and Technology, Vol 3, Issue 4, pp. 49-55, April 2018.

16. Dr. C. Rajabhushanam, V. Karthik, and G. Vivek, "Elasticity in Cloud Computing", International Journal of Innovative Research in Management, Engineering and Technology, Vol 3, Issue 4, pp. 104-111, April 2018.

17. K. Rangaswamy and Dr. C. Rajabhushanamc, "CCN-Based Congestion Control Mechanism In Dynamic Networks", International Journal of Innovative Research in Management, Engineering and Technology, Vol 3, Issue 4, pp. 117-119, April 2018.

18. Kavitha, R., Nedunchelian, R., "Domain-specific Search engine optimization using healthcare ontology and a neural network backpropagation approach", 2017, Research Journal of Biotechnology, Special Issue 2:157-166

19. Kavitha, G., Kavitha, R., "An analysis to improve throughput of high-power hubs in mobile ad hoc network", 2016, Journal of Chemical and Pharmaceutical Sciences, Vol-9, Issue-2: 361-363

20. Kavitha, G., Kavitha, R., "Dipping interference to supplement throughput in MANET", 2016, Journal of Chemical and Pharmaceutical Sciences, Vol-9, Issue-2: 357-360

21. Michael, G., Chandrasekar, A.,"Leader election based malicious detection and response system in MANET using mechanism design approach", Journal of Chemical and Pharmaceutical Sciences(JCPS) Volume 9 Issue 2, April - June 2016.

22. Michael, G., Chandrasekar, A.,"Modeling of detection of camouflaging worm using epidemic dynamic model and power spectral density", Journal of Chemical and Pharmaceutical Sciences(JCPS) Volume 9 Issue 2, April - June 2016

23. Pothumani, S., Sriram, M., Sridhar, J., Arul Selvan, G., Secure mobile agents communication on intranet,Journal of Chemical and Pharmaceutical Sciences, volume 9, Issue 3, Pg No S32-S35, 2016

24. Pothumani, S., Sriram, M., Sridhar, Various schemes for database encryption-a survey, Journal of Chemical and Pharmaceutical Sciences, volume 9, Issue 3, Pg NoS103-S106, 2016

25. Pothumani, S., Sriram, M., Sridhar, A novel economic framework for cloud and grid computing, Journal of Chemical and Pharmaceutical Sciences, volume 9, Issue 3, Pg No S29-S31, 2016

26. Priya, N., Sridhar, J., Sriram, M. "Ecommerce Transaction Security Challenges and Prevention Methods- New Approach" 2016 ,Journal of Chemical and Pharmaceutical Sciences, JCPS Volume 9 Issue 3.page no:S66-S68

27. Priya, N.,Sridhar,J.,Sriram, M."Vehicular cloud computing security issues and solutions" Journal of Chemical and Pharmaceutical Sciences(JCPS) Volume 9 Issue 2, April - June 2016

28. Priya, N., Sridhar, J., Sriram, M. "Mobile large data storage security in cloud computing environment-a new approach" JCPS Volume 9 Issue 2. April - June 2016

29. Anuradha.C, Khanna.V, "Improving network performance and security in WSN using decentralized hypothesis testing "Journal of Chemical and Pharmaceutical Sciences(JCPS) Volume 9 Issue 2, April - June 2016.

\section{AUTHORS PROFILE}

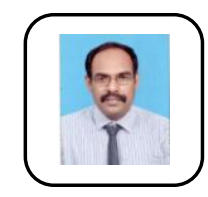

G.Michael Associate Professor, Department of Computer Science \& Engineering, Bharath Institute of Higher Education and Research, Chennai, India

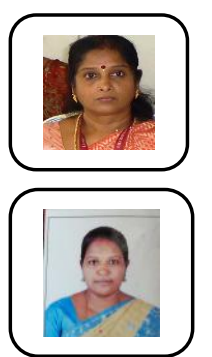

C. Nalini Associate Professor, Department of Computer Science \& Engineering, Bharath Institute of Higher Education and Research, Chennai, India

C. Geetha Assistant Professor, Department of Computer Science \& Engineering, Bharath Institute of Higher Education and Research, Chennai, India 